$\begin{gathered}\text { Journal of Business Management and } \\ \text { Economic Research }\end{gathered}$
2020, 4 (4) DOI: $10.29226 / T R 1001.2020 .214$
Journal Homepage: $\underline{\text { https://www.jobmer.org }}$

\title{
Investigating the Existing Barriers in Export Performance of Small and Medium Scale Enterprises Case Study: Iran's Isfahan Stone Industrial Cluster
}

\section{Morteza Raei Dehaghi}

Assistant Professor, College of Management and Accounting, Department of Industrial Management, Mobarakeh Branch, Islamic Azad University, Mobarakeh, Isfahan, Iran

dr_mraeidehaghi@yahoo.com.ph

\begin{abstract}
The governments across the world have recognized the importance of small and medium-scale enterprises and their role in economic growth, social solidarity, employment, and regional and local development. This study aims to investigate the existing barriers in export performance of small and medium-scale enterprises. It is causal research and has an applicable purpose. In order to test the proposed hypotheses and perform statistical analyses, field study has been utilized. The required data has been gathered by means of questionnaire. The statistical population included 1400 managers and deputies of Isfahan Stone Industrial Cluster among which 211 persons were selected. Confirmatory factor analysis was employed to confirm validity and reliability of the questionnaire which was obtained through the Cronbach's alpha coefficient equal to 0.744 . The hypotheses were tested by means of structural equation modeling and Lisrel software. Given data analysis, the results indicate that internal barriers of the firm, including companies' internal barriers and product barriers, as well as external barriers, such as industry entry barriers, market barriers and environmental barriers, are effective on export performance of the firm.
\end{abstract}

Keywords: Internal barriers to exports, external barriers to export, export performance, small and medium- scale firms, Isfahan stone industrial cluster

\section{Suggested Citation:}

Dehaghi, M. R. (2020). Investigating the Existing Barriers in Export Performance of Small and Medium Scale Enterprises Case Study: Iran's Isfahan Stone Industrial Cluster. Journal of Business Management and Economic Research (JOBMER), Vol: 4, Issue: 4, 335-350. 


\section{Introduction}

The ultimate goal of any economy is to enhance people's welfare through sustainable growth and development which is impossible in the current world without paying attention to the industry and industrialization. Many believe that higher welfare can be achieved by improved industrial performance as the driving engine of economic growth (Mohtashami, 2015). The idea of developing export of non-oil products has long been considered extensively by economic experts and has passed many ups and downs theoretically and practically. Clearly, a vast country like Iran that has affluent natural resources must be able to obtain a special status by manufacturing and exporting non-oil products in the world especially the Middle East.

But during the past fifty years, oil has not only been the most important export product but the effective and dictating factor of economic plans and changes. Today, production and export play a major role in the framework of any healthy economy in the global economy. The role of export and its importance in the growth and prosperity of economy of developing countries has been recognized well. One of the important economic issues that many countries especially developing countries are now suffering is deficit in external balance and lack of currency which will be led to foreign exchange imbalance, decreased value of national currency and capital outflow. Although there are various ways to supply foreign exchange deficit but it must be stated that the most suitable and fundamental method is increased exports which is a basic and economic solution.

Export development has played an important role in economic development of some countries and specifically the newly industrialized Southeast Asia. However, it is noteworthy that simultaneous implementation of two strategies of import substitution and export development has been the key to success of the above-mentioned countries. Developing export of non-oil products has a specific priority not only from foreign exchange viewpoint but also in terms of creating employment in the country. It seems that variety of export of non-oil products is effective economically and as a political solution to proceed the government's purposes. Fortunately, the authorities and people nowadays know that the real and sustainable progress of economy depends to a large extent on export development and achieving secure markets in various countries.

The governments across the world have recognized the importance of small and medium-scale enterprises and their role in economic growth, social solidarity, employment, and regional and local development. Due to recognizing the potential of growth of small and medium-scale enterprises, most governments in developing countries have preferred them through supports and other incentives. Preferably, small enterprises must be supported comprehensively and through different institutions at 
all export levels. The major reason for helping the small and medium-sized enterprises is to improve their competitiveness in global markets and help develop the export of a country. Unfortunately, small and medium-scale enterprises do not constitute a homogenous group and the research has shown that needs of enterprises are changed in terms of the level of export development and industry type. Export development programs of the government should be designed and executed considering the audience or target companies. Moreover, these programs must be evaluated regularly for offering appropriate services to those needs and also, they must correspond with the customers' needs (Ebrahimi et al., 2013). Export development in small and medium-scale enterprises not only has positive effects on trade balance but leads to more employment. In all newly industrialized economies, small and medium-scale enterprises have a major role in the development strategy based on increased export. Studies show that small and medium-scale enterprises have allocated 25-30 percent of the global export averagely. In the US, small and medium-scale enterprises allocate nearly 33.7 percent of export. This is equal to 31 percent in the EU countries, about 40 percent in India, 18 percent in Indonesia, more than 25 percent in Pakistan, about 20 percent in Philippines, and 60 percent in China. Increasing role of small and medium-scale enterprises in export of various countries has been due to adopting appropriate policies. Many countries have proposed various policies to develop, reinforce and enhance competitiveness of small and medium-scale enterprises in the global markets. There might be few countries in which there are not any rules to support such enterprises (Monavarian et al., 2012).

Despite numerous potentials of small and medium-scale enterprises for export development, several barriers and limitations may decrease activity, growth and competitiveness of these enterprises and thus, their access to a suitable market share. According to a survey by one of the non-governmental organizations in the US, 95.1 percent of small and medium-scale enterprises is destroyed up to five years after beginning to work. The changing economic environment and socio-economic forces decrease the effect of policies and services offered by public firms. Export development policies are effective on export performance directly and indirectly. Export development programs can be effective on export performance through enterprises' access to export capabilities or elimination of export barriers. Other study explored the effect of export support programs and export performance. They believe that policymakers should help small and medium-scale enterprises overcome export barriers. Export barriers of small and medium-scale enterprises root in various factors. Some problems are related to the small nature of these firms and lack of a prominent individual and significant role in the industry. Some of them are due to market inefficiency and some other are because of weak and discriminatory policies. The studies reveal that the barriers facing small and medium-scale enterprises are different in various countries depending on the level of development or economic system. Thus, 
the present study seeks to answer this question: how is the effect of pre-identified factors on export performance of Isfahan Stone Industrial Cluster which are mostly small and medium-scaled?

\section{Theoretical Review}

Various studies have been conducted about the effective factors on export performance. In each study, some variables have been taken into account which influence export performance directly or indirectly according to the author's viewpoint. The variables under study are to some extent extensive so that contradictory conclusions, ambiguities and findings have also been obtained. Most primary studies on export have been about recognition of exporters from non-exporters. It means that the internationalization process of the company has mostly been considered. Since then, the researchers explored the effective external factors on export behavior like accurate incentive programs. In the third phase, the researchers investigated the factors related to behavior of companies which were proportional to export and its results. The researchers of the fourth group explored the factors which were effective on export performance or success of companies.

For instance, Kasikead et al. (1996) explored the effect of three factors of objective characteristics of a firm, variables associated with recognition of export (export size and experience, export motivation, export difficulties, competitive advantages) and commitment to export (distinct export sector, entering a foreign market and customer selection standards, permanent visiting of the export market, planning and export control) on the export performance in European countries through proposing a model. White et al. (1998) analyzed several measurement methods of export performance in service sector. Valos and Baker (1996) proposed a model for the effective variables on export performance in Australia. They divided the variables into two classes, i.e. intangible (attitude, skill, knowledge) and tangible (distribution, product, customer relationship, control, suppliers). Shoham and Kropp (1998) explored the effect of marketing mix variables (product, price, place, and promotion) on export performance. In the same year, Zou and Stan (1998) introduced a framework for classification of various effective factors on export performance through reviewing previous studies. This framework classifies the effective factors on export performance into two dimensions: controllability versus uncontrollability and interorganizational versus extra-organizational. By combining these dimensions, four quarterages are created for division of the effective factors on export performance.

Deal et al. (2000) investigated the effect of firm characteristics (firm size, degree of perceived barriers to entry and years of the firm engagement in business), firm competency (export experience) and export marketing strategies (focus on the market versus variability as well as acting actively versus acting passively) on export performance of the firm (Kordenaeeij et al., 2005). 
Some researchers found evidences of the positive effect of export on economic growth and some studies indicate that export development will create more employment comparing with import substitution. There are also evidences that show export development and import substitution have positive and negative correlation with total factor productivity, respectively. Shabani et al. (2012) indicated that internal barriers of a firm, barriers to product, market barriers and macro-environmental barriers have a negative, converse and significant relationship with export performance and barriers to entering an industry do not have a significant relationship with export performance. The study of (Haddoud et al., 2017) also finds that whilst both informational and experiential export promotion programs improved all forms of SMEs' relationships, only experiential forms had an indirect effect on export performance. Further, only relationships with foreign buyers had a positive impact on export performance

\subsection{Internal and external barriers to export}

Wach describes that the path chosen for internationalization depends on both internal and external factors and they can be classified as (i) exporting modes like indirect, direct and cooperative export, (ii) contractual modes like contract manufacturing, assembly operations and licensing and (iii) investment modes like foreign branch, joint venture subsidiary and wholly owned subsidiary (Wach, 2014c).

External environmental (or exogenous) barriers include issues associated with economic, political-legal and socio-cultural environment of the external market in which the firm is operating in (Wach, 2015). Internal barriers to export are related to lack of adequate resources. For instance, the issue related to correspondence and supplying the importer's standards, proportional designing for the export market, the issues associated with weakness of export unit, lack of a capable human resource to control export activities, inability in financing export activities, and lack of adequate information about external markets are effective on export performance. These barriers can be divided into two sections, i.e. firmrelated barriers and product-related barriers.

Many scholars have found that many export problems originate from the external environment. The nature of such problems is diverse: difference in demands and priorities of the foreign customer, unfamiliar rules and situations, competitive intensity, foreign exchange rate and limit. It is possible to classify these problems as the barriers related to the industry, export market and the macro environment (Shabani et al., 2012). Modern approaches by SMEs are also effective in handling most of the traditional challenges posed in internationalization. Firms have evolved in handling internal barriers by finding dynamic solutions from within. SMEs need support from governmental and policy makers to overcome external barriers (Narayanan, 2015). 


\section{Literature Review}

Numerous studies have been carried out about the existing barriers on export performance of small and medium-scale enterprises. Some of these studies are mentioned below.

AL-Hyari et al. (2012) divided the export barriers into two internal and external classes. Internal barriers include information weakness of foreign markets, deficiency in the required abilities for export, financial barriers, product-related barriers and barriers associated with procurement logistics. And external barriers include the current procedures in export activities, inadequate governmental support, intensive competitions in foreign markets and environmental, political, economic and cultural barriers.

Serra et al. (2012) examined the effective factors on tendency toward export of textile companies in England and Portugal. The most important factors on companies' tendency were firm size, competitive advantage, technology and purposefulness.

Ebrahimi et al. (2013) believed that six factors including internal factors, domestic demand conditions, the related and supporting industries, strategy, structure and competition, role of the government and unpredicted events are effective on weakness of stone export in Lorestan province considering the Diamond Model by Porter.

In a survey, Alrashidi (2013) pointed out that export barriers of companies include lack of efficient and educated personnel in export, lack of managers' experience in foreign markets, little awareness on research in foreign markets, lack of support of the government from export, high cost of importing the raw material, changing of monetary policies and tax, intensive competition and domestic security of countries.

Shah Hosseini and Faghih Aliabadi (2013) explored and identified the challenges of export development of technical and engineering services in oil and gas. This study was carried out thru qualitative method and content analysis approach. They obtained a conceptual model consisting of eight main themes including the developmentalist government, industry, oil and gas industry, legal factors, financial factors, technical technological factors, structural factors and managerial systems.

Yusefi et al. (2014) divided internal barriers to export into factors of firm, product and marketing. They concluded the positive effect of these factors on decreased export.

In a survey, Ranjbar et al. (2014) divided external barriers to export into factors of industry, market and macro environment. The results have confirmed the positive effect of these factors on decreased export. 
Karbasi and Tohidi (2015) estimated the demand function for pistachio export in Iran. The results show that preparing and implementing supportive policies to decrease marginal cost of pistachio manufacturers is essential given the demand conditions in destination markets.

Pidani and Mahmood (2016) explored the relationship between the use of exploitation capacity of firms and increased competition in the global markets in ASEAN countries. The results reveal that there is a positive and significant correlation between the use of capacity of small and medium-scale enterprises and their export level. Similarly, capacities, competitiveness and organizational performance are important for the growth of small and medium-scale enterprises as priorities.

Amiri Kachami and Chubchian (2017) investigated date export barriers in south of Kerman province. The results demonstrated that four factors explain relatively 73 percent of date export barriers. The highest eigen_value is related to the factor of lack of knowledge which has allocated 43 percent of export barriers in south of Kerman province. The next factors are policymaking, infrastructure and financial factors.

Hassangholipour et al. (2017) identified and prioritized the key success factors of decorative stone exporters in Iran. The obtained results reveal that Iran has an appropriate status in the stone industry in the world in terms of production level of the mines and processing units as well as stone consumption but does not have a suitable status in the field of exporting and importing of worked and unworked stones. It is necessary to improve the competitive status of Iran in decorative stone export through identification of the key success factors in exportation.

Breckova (2018) mentioned that regulation/bureaucracy and the need for compliance with regulations or local customs proved to be the strongest perceived barriers to foreign trade also year-on year. It can be argued that high bureaucracy is generally the main barrier of domestic SMEs, which may be reflected in their lower performance.

Despite the above-mentioned studies, other studies have also been conducted such as Nazemi and Khani (2010), Gharehche and Shamshiri (2010), Khattak et al.'s (2011), Rahmani et al. (2013), Mehrabani and Tayebnia (2013), Pourashraf (2014), Karani et al. (2014) and Justin (2017). This issue has been explored in each study using various methods and data.

\section{Conceptual Model}

According to the literature review, the research conceptual model is summarized in Figure

1. The framework defines the connection between the main concepts of a study. This study 
seeks to investigating the existing barriers in export performance of small and medium-sized enterprises.

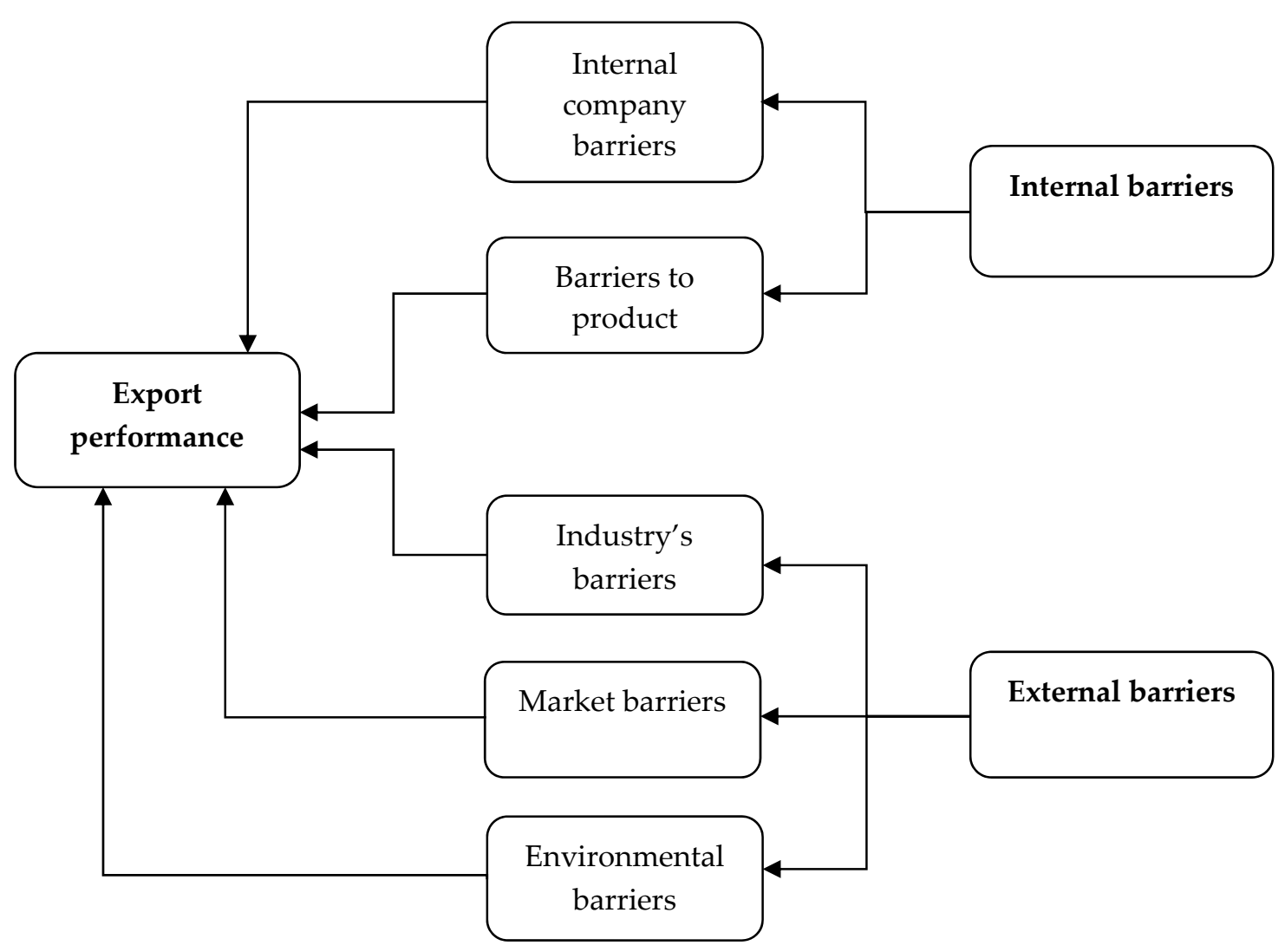

Figure 1. Conceptual model

\section{Research Hypotheses}

Given the nature of the model, the hypotheses are formulated as below:

Hypothesis 1. Internal company barriers are effective on export performance of the firm.

Hypothesis 2. Product barriers are effective on export performance of the firm.

Hypothesis 3. Industry entry barriers are effective on export performance of the firm.

Hypothesis 4. Market barriers are effective on export performance of the firm.

Hypothesis 5. Environmental barriers are effective on export performance of the firm. 


\section{Research Methodology}

This study is applicable from objective aspect and is causal from methodological aspect since the researcher intends to explore the effective barriers on export performance of small and medium- scale enterprises. Field study has been utilized for data collection.

The required data was gathered using the questionnaire. Reliability of the questionnaire was confirmed thru the Cronbach's alpha coefficient and its validity was determined thru SPSS software. The obtained Cronbach's alpha coefficient was equal to 0.744 that showed adequate reliability of the questionnaire. The statistical population included managers and deputies at Isfahan Stone Industrial Cluster (1400 stone cutting units). Considering that the structural equation modeling was used for data analysis, 211 persons were selected as the sample size via the below formula:

$5 \mathrm{q} \leq \mathrm{n} \leq 15 \mathrm{q}$

Finally, structural equation modeling was carried out with the help of Lisrel software in three sections. First, goodness of the model, i.e. data quality is explored. Second, factor analysis of the model, i.e. quality of questions is explored and third, t-statistic is used for testing of hypotheses.

\section{Research Findings}

\subsection{Factor analysis- the first step}

The first section explores goodness of the model based on the collected data.

Table 1. Exploring goodness indexes

\begin{tabular}{|c|c|c|c|}
\hline Goodness index & \multicolumn{2}{|c|}{ The standard value/source } & The estimated \\
\hline Chi square to degree of freedom (x2/ df) & $<3$ & $\begin{array}{l}\text { Carmines and } \\
\text { McIver (1981) }\end{array}$ & 1.98 \\
\hline $\begin{array}{l}\text { Root mean square error of approximation } \\
\text { (RMSEA) }\end{array}$ & \multirow[b]{2}{*}{$<0.08$} & \multirow[t]{2}{*}{ Hair et al. (1998) } & 0.068 \\
\hline Rot mean square residual (RMR) & & & 0.052 \\
\hline Non-normed fit index (NNFI) & $>0.9$ & \multirow[b]{3}{*}{ Bentler and Bonett (1980) } & 0.92 \\
\hline Comparative fit index (CFI) & $>0.9$ & & 0.93 \\
\hline Incremental fit index (IFI) & $>0.9$ & & 0.93 \\
\hline Goodness of fit index (GFI) & $>0.8$ & $\begin{array}{l}\text { Etezadi-Amoli and } \\
\text { Farhoomand (1996) }\end{array}$ & 0.80 \\
\hline
\end{tabular}


As it is observed in Table 1, all goodness indexes are according to the standard value and show that the model's goodness is confirmed by the collected data.

\subsection{Factor analysis- the second step}

In the second step, the effective indexes on export performance of small and medium -scale enterprises are explored that are observed in diagrams 1 and 2.

As it is observed in Diagrams 1 and 2, all goodness paths are according to the standard value and indicate confirmed quality of questions.

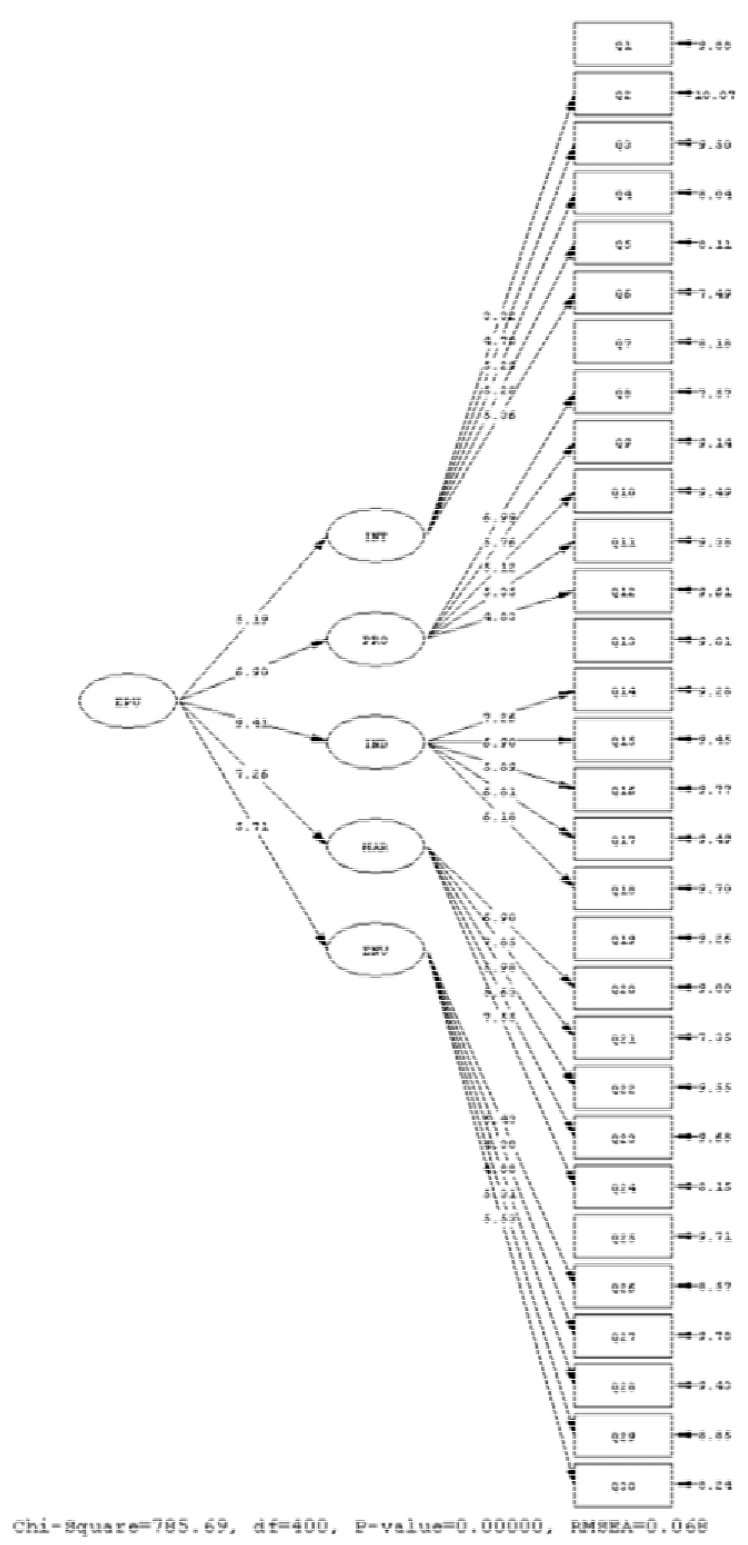

Diagram 1. P-value model for factor analysis- the second step 


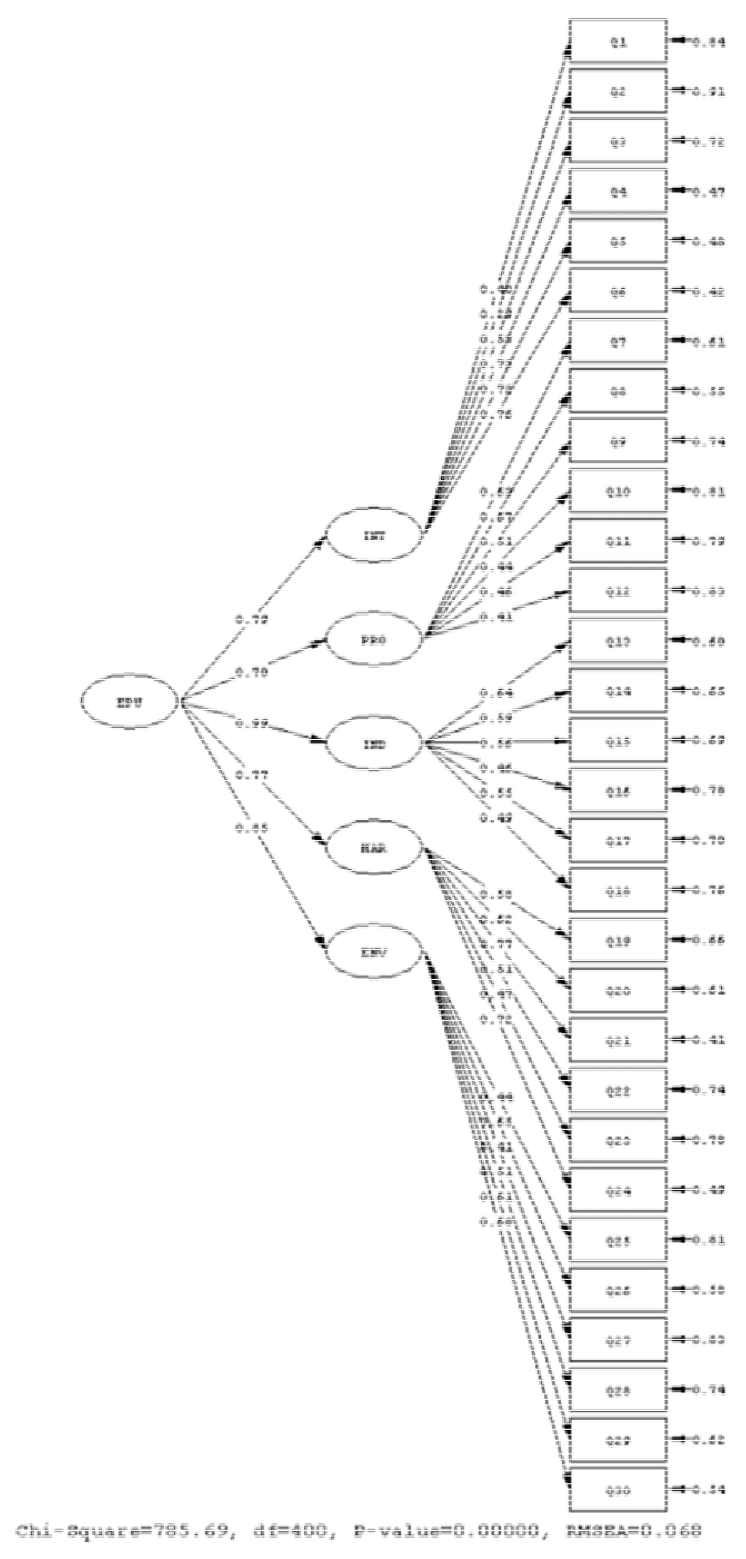

Diagram 2. Model of standard coefficients for factor analysis- the second step

\subsection{Testing of hypotheses}

In order to explore significance of the indexes, t-statistic was used. Summary of the results is shown in Table 2. 
Table 2. Results of hypotheses

\begin{tabular}{|l|c|c|l|}
\hline \multicolumn{1}{|c|}{ Hypotheses } & t-statistic & Standard coefficient & \multicolumn{1}{c|}{ Result } \\
\hline 1: Internal barriers & 5.19 & 0.79 & The hypothesis is confirmed \\
\hline 2: Product barriers & 6.90 & 0.70 & The hypothesis is confirmed \\
\hline 3: Industry entry barriers & 9.41 & 0.99 & The hypothesis is confirmed \\
\hline 4: Market barriers & 7.26 & 0.77 & The hypothesis is confirmed \\
\hline 5: Environmental barriers & 5.71 & 0.85 & The hypothesis is confirmed \\
\hline
\end{tabular}

As it is observed in Table 2, given that all t-statistics are equal to 5.19-9.42 and the values are not in the interval 1.96 to -1.96 , it can be concluded that all hypotheses are significant. It means that internal barriers, barriers to product, barriers to entering an industry, market barriers and environmental barriers have a significant effect on export performance of the firm. On the other hand, path coefficients are equal to $0.70-0.85$ and are positive and significant. Given the obtained results from the hypotheses, internal barriers of the firm, barriers to product, barriers to entering an industry, market barriers and environmental barriers have a positive effect on export performance of Isfahan Stone Industrial Cluster and all hypotheses are confirmed.

The results of hypotheses 1 and 2 are consistent with the results of studies performed by Shabani et al. (2012) and Yusefi et al. (2014), because they concluded, too, that internal barriers of the firm like lack of knowledge related to export markets or inadequate information about the market as well as low quality of the products or not manufacturing the products proportional to the customers' needs in different markets can be effective on failure of export performance.

The obtained result from hypothesis 3 is not consistent with the result of Shabani et al.'s study (2012), since they concluded that barriers to entering an industry are effective on failure of export performance and also, they are not effective on export performance. But the result of this hypothesis is consistent with that of Ranjbar et al.'s study (2014).

The results of hypotheses 4 and 5 are consistent with the results of Shabani et al. (2012) and Ranjbar et al.'s study (2014), as they concluded that one of the effective factors on failure of export performance can be market barriers such as cultural and linguistic differences, the foreign customer's recognition of the brand. Besides, other macro-environmental variables contain the factors which are out of the company's control such as foreign exchange rate, export promotion policies, international trade agreements, and so on. Public institutions can increase export barriers, for instance, lack of rules which support the exporters and lack of export infrastructures and shipping problems are the effective factors on failure of export performance. Exporters suffer from weakness in collecting and supplying information about identification of export opportunities and lack of suitable promotion programs, 
because lack of knowledge about foreign markets is one of the major effective factors on export. The government can have a main role in creating the required infrastructures to facilitate export. On the other hand, exporters in some developed countries are faced with infrastructural problems. A product which has been designed well and produced with a high quality cannot safely be reached to the importing country without a suitable transportation system.

\section{Conclusion and Recommendations}

Considering the role of export in creating employment opportunity and supplying foreign currency for imports especially in developing countries, permanent presence in the international markets is vital for many countries from political and economic aspects and survival of economy of countries depends on presence in international markets. From this aspect, accurate decision-making and adopting appropriate policies at various levels have become essential given the complexity of increasing competitions. Thus, it can be concluded that many problems and barriers to export development in small and medium-sized enterprises have structural nature and these enterprises cannot overcome them alone. Moreover, many of the existing barriers root in information weakness of the firms and the current process of export. Therefore, proposing strategies to provide the required business information for exporters and facilitate foreign trade especially in export field is one of the strategic necessities in export development.

Hence, the following applied recommendations are proposed:

- Companies which intend to enter foreign markets for the first time must gain the related information to be able to achieve suitable knowledge about these markets or implement their own policies and programs.

- It is recommended to utilize high quality raw material and produce high quality new products to achieve foreign customers' satisfaction and finally, enhance export performance of the firm.

- It is recommended to develop the company through cooperation with competitive firms which act in the same field to enjoy high technical level and technological power and manufacture products thru cooperation agreements and distribute them in foreign markets by offering competitive prices proportional to the expenses.

- It is recommended to hire proficient people from the countries which intend to be active there and make it possible to become familiar with cultural characteristics and differences of the intended country so that they can create an appropriate market through manufacturing products that are proportional to their culture. 
- It is recommended to exploit the government's supports maximally by aligning with the enacted rules and regulations by the government in order that they can increase their liquidity for purchasing suitable raw material and supplying expenses such as warehousing, buying equipment, shipping, etc. thru receiving loans and facilities.

\section{Acknowledgment}

The author is extremely grateful to Engineer Mohammad Jafari Fesharaki for his administrative and technical support in the process of this study.

\section{References}

Al-Hyari, K., Al-Weshah, G., \& Alnsour, M. (2012). Barriers to internationalization in SMEs: evidence from Jordan. Marketing Intelligence \& Planning, 30 (2), 188 - 211.

Alrashidi, Y.A. (2013). Exporting motivations and Saudi SMEs: An Exploratory Study, Asian Business Research Conference $\left(8^{\text {th }}\right)$, Bangkok.

Amiri Kachami, S., \& Chubchian, Sh. (2017). Exploring date export barriers in south of Kerman province. Journal of Business Research, 15 (84 - 85), 74-84.

DeaL, D. L., Menguch, B., \& Myers, C. P. (2000). Revising firm characteristics strategy and export performance relationship. Industrial Marketing Management, 29, 461-477.

Ebrahimi, A., Jaferi, A., \& Nasrolahi Vasati, L. (2013). Measuring the status of stone export performance. Quarterly Journal of Strategic Management Studies, 13, 163-181.

Ghareche, M., \& Shamshiri, F. (2010). The advantages of using services of export management companies in export development strategies of small and medium-sized enterprises. Journal of Strategic Management Studies, 65-85.

Haddoud, M.Y., Jones, P., \& Newbery, R. (2017). Export promotion programmes and SMEs' performance. Exploring the network promotion role. Journal of Small Business and Enterprise Development, 24(1), 68-87.

Hasangholipour, T., Aghazadeh, H., \& Mehdizadeh, M. (2017). Identification and prioritization of the success key factors in companies exporting decorative stones in Iran. Journal of Business Research, 15 (84 - 85), 49-61.

Justin, P., Sundar, P., \& Parul, G. (2017). Exporting challenges of SMEs: A review and future research agenda. Journal of World Business, 52(3), 327-342.

Karani, A., Jalalvand, W., \& Shahiki Tash, M. (2014). Exploring effectiveness and prioritization of the effective indexes on the firms' barriers to entry in the industry sector in Iran (via fuzzy AHP technique). Quarterly Journal of Fiscal and Economic Policies, 8, 103-124.

Karbasi, A., \& Tohidi, A. (2015). The effective factors on pistachio export in Iran. Iranian Journal of Agricultural Economics, 91-112. 
Kasikead, K. S., Piercy \& Ioannidis, C. (1996). Determinants of export performance in a European context. European Journal of Marketing, 30, 6-35.

Khattak, J.K., Arslan, M., \& Umair, M. (2011). SMEs export problems in Pakistan. Business Management and Economics Journal, 2(5), 192-199.

Kordenaeeij, A., Anvari Rostami, A., \& Dehyadgari, S. (2005). Exploring the relationship between dimensions of competitive advantage and export performance of decorative stone exporters in Iran. Iranian Journal of Trade Studies, 10 (37), 133-152.

Mehrabani, V., \& Tayebnia, A. (2013). Structure of domestic market and export performance of industrial firms in Iran. Quarterly Journal of Economic Research and Policies, 21 (68), 29-48.

Mohtashami, T., \& Mohtashami, N. (2015). Analysis of knowledge-oriented economy on non-oil export development in Iran during the economic development plans. The International Conference on Management, Culture and Economic Development.

Monavarian, A., Moghimi, S., Movahedi, M., \& Hossenzadeh, M. (2012). Explaining policymaking of export development in small and medium-sized enterprises using the Grounded Theory. Public Administration, 4 (3), 123-144.

Narayanan, V. (2015). Export barriers for small and medium-sized enterprises: A Literature Review based on Leonidou's Model. Entrepreneurial Business and Economics Review, 3(2), 105-123.

Nazemi, Sh., \& Khani, D. (2010). Identification and analysis of the most important deterrent administrative-service factors for export of non-oil products in small and medium-sized enterprises (case study: Razavi Khorasan and North Khorasan provinces). Journal of New Economy and Commerce, 203-226.

Pavla B. (2018), Export patterns of small and medium sized enterprises. European Research Studies Journal, 21(1), $43-51$.

Piddani, R.R., \& Mahmood, A. (2016). Does international competition enhance capacity utilization? Evidence from Indonesia, Philippine and Vietnam. Asian Journal of Empirical Research, 6(5), 117-130.

Pourashraf, Y. (2014). Explaining the problems and barriers of export development in Ilam province. Business Management, 6 (1), 1-20.

Rahmani Yushanluee, H., Ansari, M., Mirkazemi Mud, M., \& Ebrahimi, M. (2013). Identification and prioritization of export barriers and presenting strategies for export development in small and medium-sized enterprises (SMEs) in food industries in West Azerbaijan. New Marketing Research Journal, 1, 139-160.

Ranjbar, S., Ranjbar, H., Nosrati, B., \& Ranjbar, F. (2014). Studying and exploring external barriers to export in small and medium-sized enterprises in Kurdistan province. The International Conference on Industrial Engineering and Management.

Serra, F., Pointon, J., \& Abdou, H. (2012). Factors influencing the propensity to export: A study of UK and Portuguese textile firms. International Business Review, 21(2), 210-224.

Shabani, H.,Najafi, S., Vajdi, Kh., \& Ahmadi, S. (2012). Identification and measurement of the effect of existing barriers on export performance of small and medium-sized enterprises in Tehran province. The National Conference on Entrepreneurship and Knowledge-based Business Management, University of Mazandaran.

Shah Hosseini, M., \& Faghih Aliabadi, M. (2013). Exploring and identifying the challenges of development and exportation of technical and engineering services in oil and gas. Iranian Journal of Energy, 16 (2), 113-127. 
Shoham, A., \& Kropp, F. (1998). Explaining international performance: Marketing mix, planning, and their interaction. Marketing Intelligence and Planning, 16, 114-123.

Yusefi, S., Shirzadi, M., Akbari, M., Mohammadi, M., \& Mohammadi, R. (2014). Studying and exploring internal barriers to export in small and medium-sized enterprises in Kermanshah province. The International Conference on Development and Excellence of Business, Economy and Management.

Valos, M., \& Baker, M. (1996). Developing an Australian model of export marketing performance determinants. Marketing Intelligence and Planning, 14 (3), 11-20.

Wach, K. (2014c). Theoretical framework of the firm-level internationalization in business studies (pp. 13-30). Cartagena: Technical University of Cartagena.

Wach, K. (2015). Impact of cultural and social norms on entrepreneurship in the EU: Cross-country evidence based on GEM survey results. Zarządzanie Kulturze, 16(1), 15-29.

White, G., \& Ryans (1998). Measuring export performance. International

Marketing Review, 15, 188-204.

Zou, S., \& Stan, S. (1998). The determinants of export performance. International Marketing Review, 15, 333-356. 